\title{
PARECERES
}

34.142

\section{Consultor Geral da República}

Proposta de dispensa de funcionário, que reconsiderou seu pedido.

\section{PARECER}

N. ${ }^{?}$ de referência: $520-Z$

Verifica-se do processo anexo que Jox̃o Aristides Wiltgen, Inspetor de Ensino Secundário, pedira dispensa de sua função, em 14 de fevereiro de 1951, abandonando o em. prêgo.

Sem providência por parte do Ministério que até continuou a pagar os salários do servidor a seu procurador, reconsiderou êle, em 8 de dezembro de 1954, seu pedido de exoneração, quando repôs os vencimentos ilegitimamente recebidos.

Em 1957, renovou seu requerimento de 8 de dezembro de 1954, pretendendo designação de estabelecimento para fiscalizar.

O Ministério, apoiado pelo D.A.S.P., não obstante êsses dois requerimentos, quer atender ao primeiro, datado de 1951, preparando, para isso, decreto de dispensa, submetido à eminente apreciação e assirratura do Excelentissimo Senhor Presidente da República.

Requisitado, pelo Chefe do Govêrno, o parecer desta Consultoria Geral, esta aconselha a rejeição do expedimento proposto, pois o pedido de 1951, formulado há tanto tempo, fôra retratado, inequivocamente, sendo, contudo, caso de instauração de processo administrativo por abandono de emprêgo.

Com efeito, o pedido de dispensa, na frase de DuEz et DEBEYRE, não é senão ıma oferta de exoneração formulada pelo servidor publico - «elle n'est donc qu'un offre de s'en aller faite par le fonctionnaire» (Droit Adm. 1952 , n. ${ }^{\circ} 1.002$ ) - não se opera senão aceita, de sorte que como proposta, como oferta, pode ser retratada antes da aceitação. A êste respeito, a proposição do Código Suiço de Obrigações contém regra que consubstancia aspirações doutrinárias e é aplicável à espécie: - L'offre est considerée comme non avenue, si le retrait en parvient à l'autre par- tie avant l'offre ou en même temps (art. $7 .^{\circ}$ ). $\mathrm{Ou}$ mesmo se a retratação chega antes da proposta ser aceita, quando fica sem resposta por tempo razoável (Cód. Civil, artigo 1.081).

No caso pois, antes de aceito o pedido de dispensa, houve retratação, de sorte que não pode, ao parecer, o mesmo ser acolhido. Esta conclusão não obsta, contudo, a instauração de processo por abandono de função pública, para julgamento como fôr de direito. Salvo melhor juizo. Rio de Janeiro, 24 de março de 1959. - A. Gonçalves DE Oliverra, Consultor Geral da República.

«De acốrdo com o parecer do Senhor Consultor Geral da República. Em 14-4-59». (Rest. proc. ao M.E.C., em 16-5-49).

Publicado no Diário Oficial de 15-5-59, à pág. 11.494, seção I.

Exercicio de magistério, em estabelecimentos particulares, por parte dos militares da ativa.

\section{PARECER N. $505-Z$}

Consulta o Exmo. Sr. Ministro da Guerra sôbre exercicio de magistério em estabelecimentos particulares, por parte dos militares da ativa.

Aos professôres e instrutores é expresso, na proibição, o § 5.9 do Estatuto dos Militares: « $\mathrm{E}^{\prime}$ vedado aos professôres e instrutores o exercício de funções de direção, gerência e outras de caráter administrativo, em estabelecimentos de ensino civil, ou cursos particulares, embora não oficializados».

A norma é perfeitamente constitucional, conforme procuramos esclarecer no Parecer número 334-Z, de 8-11-57, aprovado pelo Presidente da República (Diário Oficial de 30 de novembro de 1957, pág. 26.878; Revista de Direito Administrativo, vol. 51, página 393). A lei pode, com efeito, limitar a ati- 
vidade do servidor civil e militar. E' «l'interdition de l'exercice de plusieurs activités concurrentes", de que fala Alain PatnTE (Traité Pratique de la Fonction Publique, 1956, pág. 83), fruto de uma legislação concebida em periodo de após guerra, em que era indispensável limitar a atividade de cada individuo a uma única ocupação, pour lutter contre le chomage, para que debaixo do sol houvesse lugar para todos.

Efetivamente, na França, os arts. $8^{\circ}, 9^{\circ}$ e 10 da Lei de 19 de outubro de 1946, na esteira da legislação esparsa, estabelecem a proibição de acumulat emprêgos privados por parte de servidores públicos (PAuL DueZ et GuY Debeyre, Traité de Droit Administratifi. 1952, pág. 665).

WALINE justifica a proibição na consideração de que deve o Estado exigir que seus servidores consagrem todo o seu tempo ao serviço público, pois, negligenciariam do serviço se, também, pudessem exercer concomitantemente atividade privada, geralmente mais rendosa (MARCEL WALINE, Droit Administratif, 1957, pág. 958).

Entre nós a proibição não se refere a servidores civis, mas, a professôres e instrutores militares (art. 30, $\S 50^{\circ}$, do Estatuto dos Militares), embora em relação a funcionários seja vedado o exercício de certas atividades (Estatutos dos Funcionários, artigo 195, números VI, VII e IX). Mas, ainda em relação aos militares da ativa em geral, há também proibição de ordem legal, - o artigo 20, n..$^{\circ}$, da Lei n. ${ }^{\circ} 1.316$, de 1951, Código de Vencimentos e Vantagens dos Militares, que admite o exercício de atividades privadas pelos militares, mediante licenciamento. O citado preceito, com efeito, prevê se licenciem os militares «para exercer atividades técnicas de sua especialidade em organizações civis».

Por outro lado, o Regulamento Disciplinar do Exército, como recorda o douto Consultor Jurídico do Ministério da Guerra, veda ao militar o exercício de qualquer profissão ou função estranha ao serviço militar sem permissão do Ministro da Guerra. Na verdade, constitui transgressão disciplinar:

«Exercer, o militar ou assemelhado, sem permissão do Ministro da Guerra, qualquer protissão ou funç̧áo estranha ao serviço militar, ou ao da repartição ou estabelecimento em que trabalhar».

- (Art. 13, n. 125 do Regulamento Disciplinar do Exército).

A permissão, ao parecer, sòmente pode ser dada, mediante licença, nos têrmos do artigo $20, n{ }^{*} \mathrm{~V}$, do Código de Vencimentos e Vantagens.

E' o parecer da Consultoria Geral da República.

Salvo melhor juizo.

Rio de Janeiro, 20 de janeiro de 1959. A. Gonçalves de Oliveira, Consultor Geral da República.

«Aprove. Em 20-3-59». (Rest. proc. M.G., em 24-3-59, por intermédio do Gab. Militar da P.R.).

Publicado no Diário Oficial de 24-3-59, pp. 6.302 a 6.303 ), seção I. 